\title{
INTERACTIONS BETWEEN FUSIDIC ACID AND PENICILLINS
}

\author{
F. O'Grady and D. Greenwood \\ Department of Bacteriology, St Bartholomew's Hospital, London E.C.I \\ Plates XVII AND XVIII
}

FUSIDIC ACID is a potent bactericidal antistaphylococcal agent, but one of its drawbacks is the presence in any staphylococcal population exceeding about $10^{6}$ cells of genotypically resistant variants that might proliferate during fusidic acid therapy. Because of this, combinations of fusidic acid with other antistaphylococcal agents have been recommended and penicillins have figured largely amongst those chosen. The wisdom of this choice has been questioned because antagonism has been demonstrated in vitro between fusidic acid and penicillins.

Reports in the literature of possible interactions between fusidic acid and penicillins are conflicting. Barber and Waterworth (1962) showed synergy between fusidic acid and benzylpenicillin in certain circumstances, and Jensen and Kiaer (1964) confirmed this, as well as reporting synergy with other agents including methicillin. On the other hand, other workers (Mouton and Koelman, 1966; Jensen and Lassen, 1969) have found antagonism against some strains of staphylococci between fusidic acid and methicillin and sometimes other penicillins including benzylpenicillin.

The present study was undertaken in an attempt to clarify the situation in view of the increasing frequency with which combinations of fusidic acid and penicillins are being used in antistaphylococcal therapy.

\section{MATERIALS AND METHODS}

Strains of coagulase-positive Staphylococcus aureus were taken at random from those isolated in the diagnostic laboratory of the hospital. Both penicillin-sensitive and penicillinase-producing strains that were sensitive on routine testing to fusidic acid and methicillin were included. Strains were designated by the first three letters of the name of the patient from whom they had been isolated, e.g. Col.

The minimum inhibitory concentration (MIC) of the antibiotics for the strains was determined by a conventional serial-dilution tube titration with small inoculum (c. $10^{4}-10^{5}$ organisms per $\mathrm{ml}$ ). Turbidimetric studies were made by inoculating $15 \mathrm{ml}$ of nutrient broth with the test organism and incubating the continuously mixed culture in the light path of a simple photometer (Watson et al., 1969) housed in an incubator at $37^{\circ} \mathrm{C}$ and connected to a continuous recorder. The system will respond to bacterial concentrations in excess of $10^{6}$ per ml. Antibiotic was added when an opacity corresponding with a viable count of about $5 \times 10^{7}$ organisms per $\mathrm{ml}$ had been reached.

The number of survivors recoverable after incubating the organism overnight in broth with the various agents alone and in combination was determined by filtering the cultures

Received 7 Sept. 1972; accepted 17 Jan. 1973.

J. MED. MICROBIOL.-VOL. 6 (1973) 
through cellulose-acetate membranes (5-cm diameter: average pore size $0.45 \mu \mathrm{m}$; Oxoid Ltd); these were then washed for $5 \mathrm{~min}$. in situ with $10 \mathrm{ml}$ sterile distilled water, which was removed by further suction before transfer of the membranes to blood-agar plates. This served the dual purpose of removing residual antibiotic and destroying any cells that might have survived in protoplast form. Counts were made of the colonies appearing on the membranes after incubation. Antibiotic concentrations approximating to 10 times the average MIC were used: fusidic acid $3 \mu \mathrm{g}$ per ml, methicillin $15 \mu \mathrm{g}$ per ml, cloxacillin $3 \mu \mathrm{g}$ per $\mathrm{ml}$. In the case of benzylpenicillin, $10 \mu \mathrm{g}$ per $\mathrm{ml}$, a high concentration relative to the MIC, was used to investigate the action of this antibiotic against weakly penicillinase-producing strains. To take account of the different susceptibility to penicillin of staphylococci exposed in larger volumes (Bigger, 1944; Gunnison et al., 1964), 10-ml samples were used, and to allow for experimental variation the tests were done in quintuplicate.

\section{TABLE I}

Minimum inhibitory concentrations of penicillins and fusidic acid for 17 strains of Staphylococcus aureus

\begin{tabular}{|c|c|c|c|}
\hline \multirow[b]{2}{*}{ Strain } & \multicolumn{3}{|c|}{ Minimum inhibitory concentration ( $\mu \mathrm{g}$ per $\mathrm{ml}$ ) of } \\
\hline & benzylpenicillin & methicillin & fusidic acid \\
\hline $\begin{array}{l}\text { Aun } \\
\text { Joh } \\
\text { Fea } \\
\text { Jon } \\
\text { Fal } \\
\text { Pea } \\
\text { Clo } \\
\text { Col } \\
\text { Bat } \\
\text { Wat } \\
\text { Cro } \\
\text { Far } \\
\text { Ric } \\
\text { Tho } \\
\text { You } \\
\text { Whi } \\
\text { Sho }\end{array}$ & $\begin{array}{l}0.01 \\
0.03 \\
0.03 \\
0.03 \\
0.03 \\
0.03 \\
\mathbf{R} \\
\mathbf{R} \\
\mathbf{R} \\
\mathbf{R} \\
\mathbf{R} \\
\mathbf{R} \\
\mathbf{R} \\
\mathbf{R} \\
\mathbf{R} \\
\mathbf{R} \\
\mathbf{R}\end{array}$ & $\begin{array}{l}1.2 \\
1.2 \\
1.2 \\
1.2 \\
2.5 \\
2.5 \\
0.3 . \\
1.2 \\
2.5 \\
2.5 \\
2.5 \\
2.5 \\
2.5 \\
2.5 \\
2.5 \\
2.5 \\
2.5\end{array}$ & $\begin{array}{l}0.075 \\
0.075 \\
0.15 \\
0.3 \\
0.3 \\
0.3 \\
0.3 \\
0.15 \\
0.075 \\
0.075 \\
0.15 \\
0.15 \\
0.15 \\
0.15 \\
0.15 \\
0.15 \\
0.3\end{array}$ \\
\hline
\end{tabular}

Morphological evidence of interaction between fusidic acid and penicillins was also obtained. Cultures were exposed in broth to the agents, alone or in combination, and samples were removed at suitable intervals, fixed overnight with 2 per cent. glutaraldehyde in 5 per cent. sucrose, washed twice in distilled water with light centrifugation and air-dried on microscope slides or cover slips. These were then either stained with the cell-wall stain of Hale (1953) and examined by light microscopy, or prepared for examination in the scanning electron microscope as described elsewhere (Greenwood and O'Grady, 1969).

\section{RESULTS}

The MIC of the relevant antibiotics for each of the strains tested is shown in table $I$.

Viable counts of samples taken at hourly intervals from broth cultures of strain Col containing $10 \times$ MIC of methicillin or fusidic acid showed that the 
rate of killing of the strain by both agents was similar and that almost all the bactericidal effect had been exerted after 6 hours' exposure (fig. 1).

Filtration studies. The numbers of survivors recovered by filtration of broth cultures of all the strains studied, after overnight exposure to agents singly or in combination, are shown in tables II and III. Of 10 penicillinase-producing strains, six showed a marked increase in the number of survivors after overnight

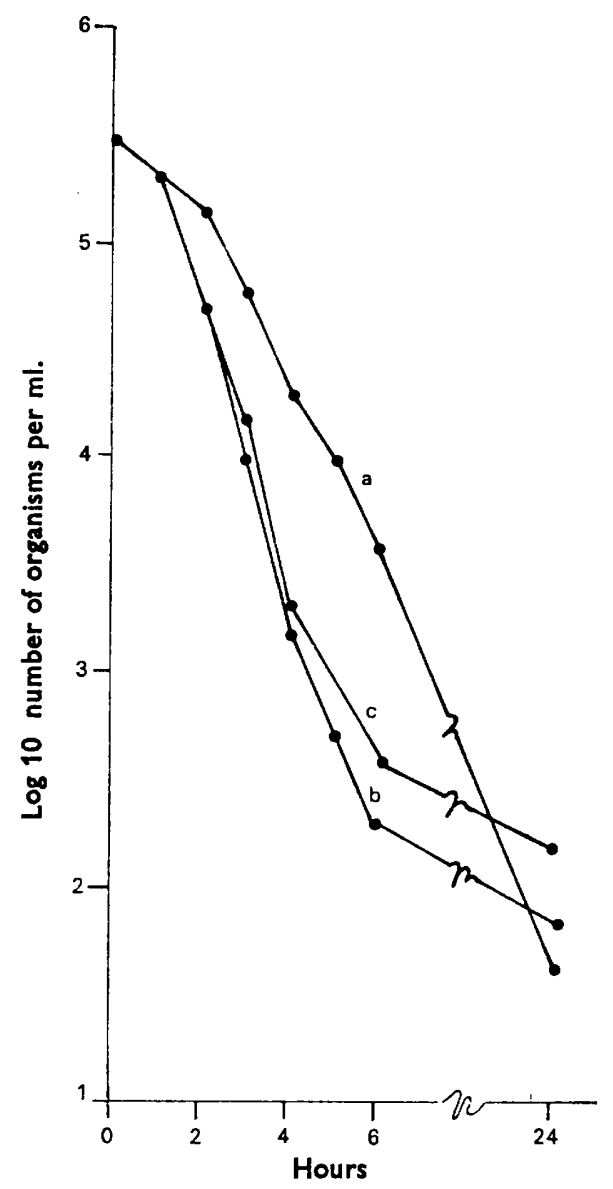

Fig. 1.-Effect on the viable count of the Col strain Staphylococcus aureus of methicillin, $15 \mu \mathrm{g}$ per $\mathrm{ml}$ (a); fusidic acid, $2 \mu \mathrm{g}$ per $\mathrm{ml}$ (b); methicillin $15 \mu \mathrm{g}$ per $\mathrm{ml}+$ fusidic acid, $2 \mu \mathrm{g}$ per $\mathrm{ml}$ (c).

exposure to fusidic acid plus methicillin compared with the number recovered after exposure to either agent alone (table II); i.e., each agent antagonised the effect of the other: two-way antagonism. Tested with the Col strain, this effect was still exhibited even when the concentration of fusidic acid was raised to $50 \mu \mathrm{g}$ per $\mathrm{ml}$. Three of the strains were inhibited by the concentration of benzylpenicillin used; they similarly showed two-way antagonism, with more survivors after exposure to the mixture than to either benzylpenicillin or fusidic acid alone. A further strain, Clo, showed two-way antagonism on exposure to fusidic acid 
plus cloxacillin. Of the remaining four penicillinase-producing strains, two (Wat and Bat) yielded more survivors after exposure to such mixtures than to

TABLE II

Viable counts of survivors recovered by membrane filtration from 10 penicillinase-positive strains of Staphylococcus aureus after overnight exposure to $10 \mu \mathrm{g}$ per ml benzylpenicillin, $15 \mu \mathrm{g}$ per $\mathrm{ml}$ methicillin and $3 \mu \mathrm{g}$ per $\mathrm{ml}$ fusidic acid, alone and in combination

\begin{tabular}{|c|c|c|c|c|c|c|}
\hline \multirow[b]{2}{*}{ Strain } & \multirow{2}{*}{$\begin{array}{l}\text { Inoculum } \\
\text { per } 10 \mathrm{ml} \\
\text { of medium }\end{array}$} & \multicolumn{5}{|c|}{ Viable count of survivors after exposure to } \\
\hline & & $\begin{array}{l}\text { benzyl- } \\
\text { penicillin }\end{array}$ & methicillin & fusidic acid & $\begin{array}{c}\text { benzyl- } \\
\text { penicillin } \\
+ \text { fusidic acid }\end{array}$ & $\begin{array}{l}\text { methicillin } \\
+ \text { fusidic acid }\end{array}$ \\
\hline $\begin{array}{l}\text { You } \\
\text { Tho } \\
\text { For } \\
\text { Ric } \\
\text { Whi } \\
\text { Col } \\
\text { Col } \\
\text { Col } \\
\text { Wat } \\
\text { Bat } \\
\text { Cro } \\
\text { Sho }\end{array}$ & $\begin{array}{c}2 \times 10^{6} \\
2 \times 10^{6} \\
10^{6} \\
10^{6} \\
6 \times 10^{5} \\
4 \times 10^{5} \\
10^{7} \\
5 \times 10^{5} \\
10^{5} \\
2 \times 10^{5} \\
10^{6} \\
5 \times 10^{5}\end{array}$ & $\begin{array}{r}C \\
C \\
C \\
17 \\
9 \\
2 \\
\cdots \\
\cdots \\
2 \\
2 \\
V \\
V\end{array}$ & $\begin{array}{r}147 \\
131 \\
78 \\
12 \\
19 \\
\ldots \\
645 \\
110 \\
2 \\
1 \\
534 \\
82\end{array}$ & $\begin{array}{c}188 \\
R \\
566 \\
60 \\
31 \\
17 \\
N \\
44^{*} \\
49 \\
153 \\
199 \\
208\end{array}$ & $\begin{array}{r}\mathrm{N} \\
866 \\
\mathrm{~N} \\
535 \\
77 \\
340 \\
\ldots \\
\ldots \\
8 \\
8 \\
221 \\
49\end{array}$ & $\begin{array}{c}\mathbf{N} \\
\mathbf{N} \\
\mathbf{N} \\
\mathbf{N} \\
\mathbf{N} \\
\dddot{C} \\
\mathbf{C} \\
547^{*} \\
10 \\
52 \\
275 \\
67\end{array}$ \\
\hline
\end{tabular}

- $50 \mu \mathrm{g}$ per $\mathrm{ml}$ fusidic acid in this experiment.

$\mathrm{V}=$ variable; $\mathrm{N}=1000-3000 ; \mathrm{C}=$ confluent $(>3000) ; \mathrm{R}=$ overgrown with fusidic-acid-resistant variants.

\section{TABLE III}

Viable counts of survivors recovered by membrane filtration from six penicillinase-negative strains of Staphylococcus aureus after overnight exposure to $10 \mu \mathrm{g}$ per $\mathrm{ml}$ benzylpenicillin, $15 \mu \mathrm{g}$ per $\mathrm{ml}$ methicillin and $3 \mu \mathrm{g}$ per $\mathrm{ml}$ fusidic acid, alone and in combination

\begin{tabular}{|c|c|c|c|c|c|c|}
\hline \multirow[b]{2}{*}{ Strain } & \multirow{2}{*}{$\begin{array}{l}\text { Inoculum } \\
\text { per } 10 \mathrm{ml} \\
\text { of medium }\end{array}$} & \multicolumn{5}{|c|}{ Viable count of survivors after exposure to } \\
\hline & & $\begin{array}{l}\text { benzyl- } \\
\text { penicillin }\end{array}$ & methicillin & fusidic acid & $\begin{aligned} & \text { benzyl- } \\
& \text { penicillin } \\
&+ \text { fusidic acid }\end{aligned}$ & $\begin{array}{l}\text { methicillin } \\
\text { + fusidic acid }\end{array}$ \\
\hline $\begin{array}{l}\text { Fal } \\
\text { Jon } \\
\text { Joh } \\
\text { Pea } \\
\text { Fea } \\
\text { Aun } \\
\text { Aun }\end{array}$ & $\begin{array}{c}2 \times 10^{6} \\
10^{6} \\
5 \times 10^{5} \\
7 \times 10^{5} \\
3 \times 10^{5} \\
6 \times 10^{5} \\
5 \times 10^{5}\end{array}$ & $\begin{array}{r}532 \\
91 \\
17 \\
5 \\
1 \\
105 \\
\ldots\end{array}$ & $\begin{array}{r}382 \\
96 \\
3 \\
6 \\
4 \\
\ldots \\
23\end{array}$ & $\begin{array}{r}\mathrm{R} \\
900 \\
158 \\
6 \\
12 \\
48 \\
9\end{array}$ & $\begin{array}{r}\mathrm{C} \\
\mathrm{N} \\
580 \\
77 \\
25 \\
51 \\
\ldots\end{array}$ & $\begin{array}{r}\mathbf{C} \\
\mathbf{N} \\
849 \\
304 \\
41 \\
\ldots \\
9\end{array}$ \\
\hline
\end{tabular}

$N=1000-3000 ; C=$ confluent $(>3000) ; R=$ overgrown with fusidic-acid-resistant variants.

benzylpenicillin or methicillin alone, but less than to fusidic acid alone, i.e., one-way antagonism of the penicillins by fusidic acid. The other two strains (Cro and Sho) yielded about the same number of survivors from the mixtures as 
FUSIDIC ACID AND PENICILLINS

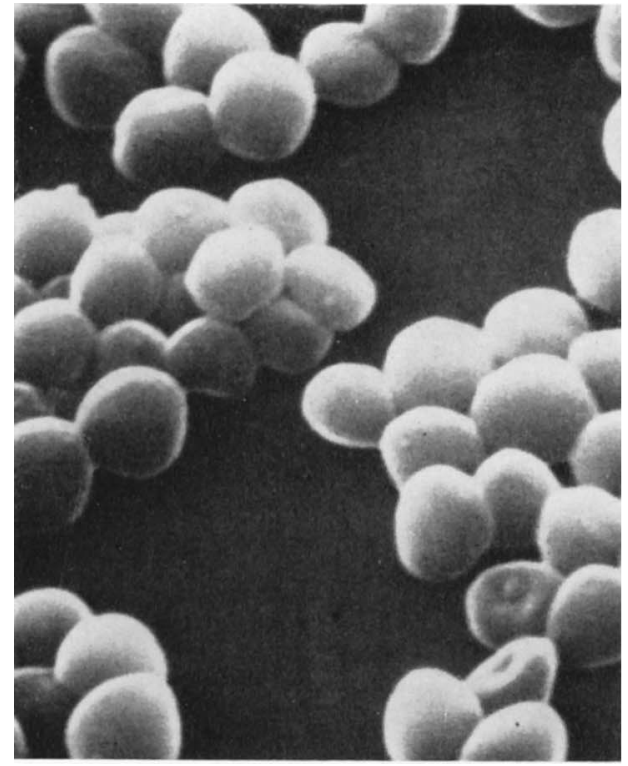

FIG. 3.-Staphylococcus aureus (Clo strain). Scanning electron micrograph $(\mathrm{SEM}) . \times 10,000$.

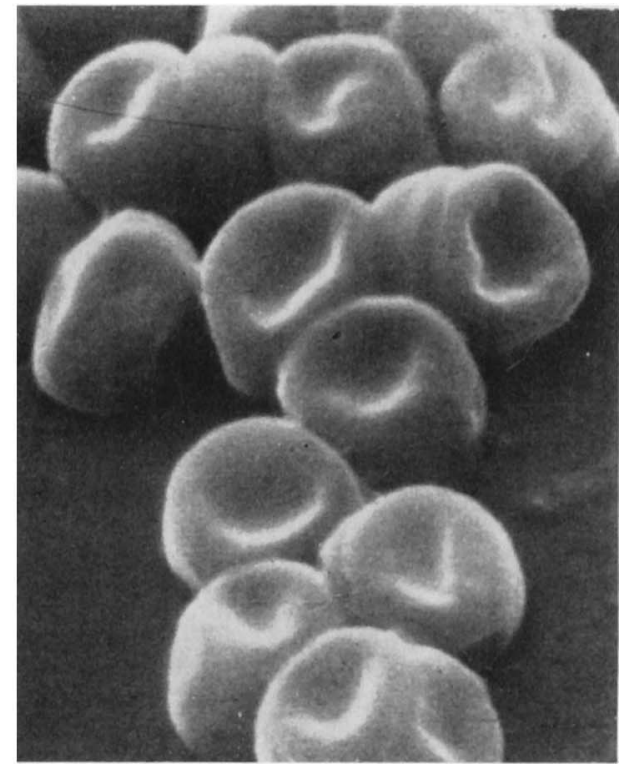

FIG. 4.-Same strain exposed to fusidic acid, $2 \mu \mathrm{g}$ per $\mathrm{ml}$, for $1 \mathrm{hr}$. SEM. $\times 13,000$.

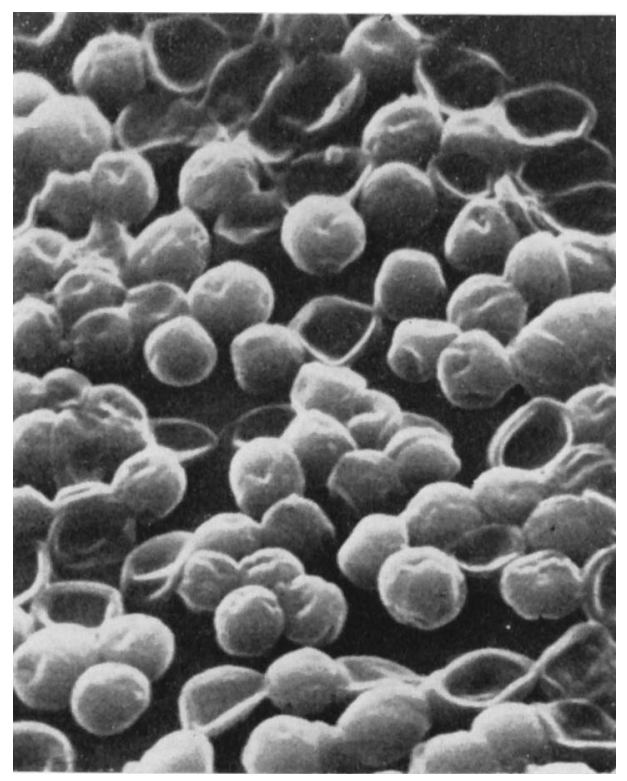

FIG. 5.-Same strain exposed to fusidic acid, $2 \mu \mathrm{g}$ per $\mathrm{ml}$, for $3 \mathrm{hr}$. SEM. $\times 6400$. 


\section{FUSIDIC ACID AND PENICILLINS}

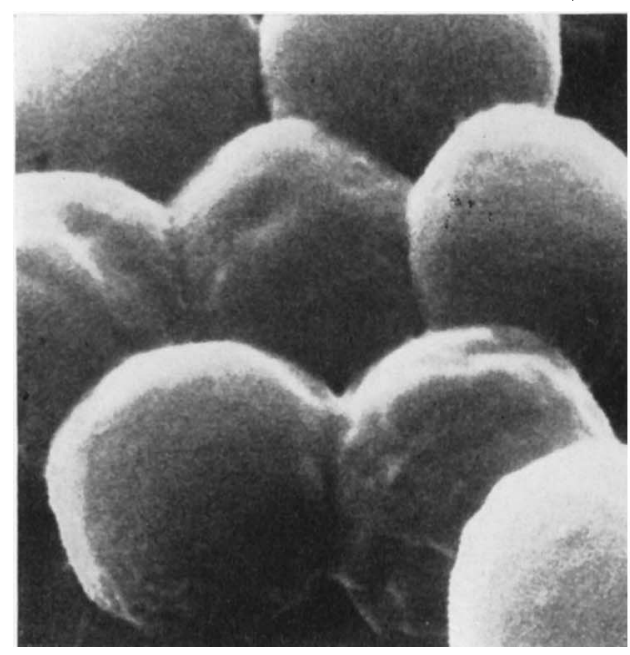

FIG. 6.-Same strain exposed to fusidic acid, $2 \mu \mathrm{g}$ per $\mathrm{ml}+$ cloxacillin, $3 \mu \mathrm{g}$ per $\mathrm{ml}$, for $1 \mathrm{hr}$. SEM. $\times 23,000$.

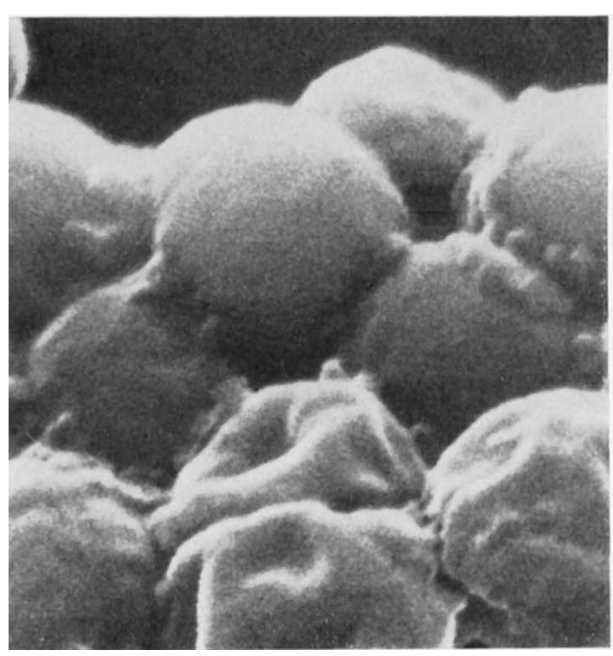

FIG. 7.-Same strain exposed to fusidic acid, $2 \mu \mathrm{g}$ per $\mathrm{ml}+$ cloxacillin, $3 \mu \mathrm{g}$ per $\mathrm{ml}$, for $3 \mathrm{hr}$. SEM. $\times 20,000$.

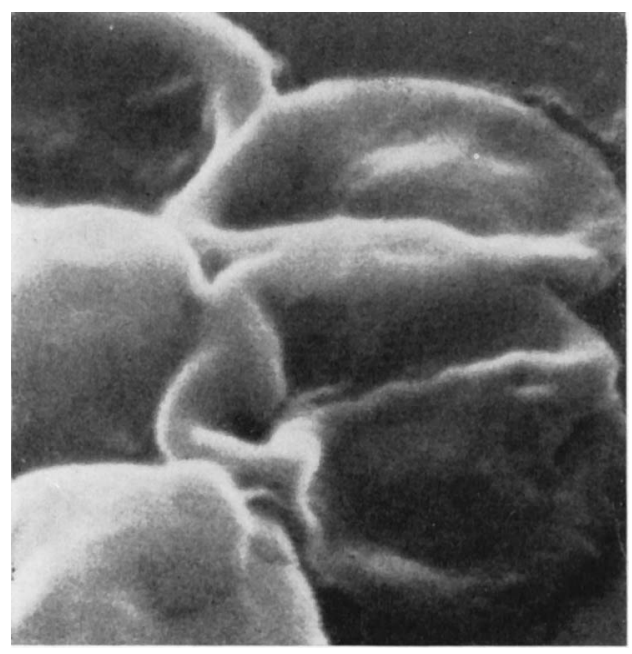

FIG. 8.- Same strain exposed to fusidic acid, $2 \mu \mathrm{g}$ per $\mathrm{ml}$ for $3 \mathrm{hr}$; cloxacillin, $3 \mu \mathrm{g}$ per $\mathrm{ml}$ added after 1 hour's exposure to fusidic acid. Note the surface damage on the collapsed cells attributable to the penicillin. SEM. $\times 26,000$. 
from the more bactericidal agents, which in one case were the penicillins and in the other was fusidic acid: i.e., there was indifference to the presence of the less active agent.

Of the six benzylpenicillin-sensitive strains tested (table III), five showed twoway antagonism by yielding more survivors after exposure to fusidic acid plus benzylpenicillin or methicillin than to any agent alone. The remaining strain

TABLE IV

Viable counts of survivors recovered from three strains of Staphylococcus aureus after overnight exposure to combinations of fusidic acid and penicillins that were added simultaneously or consecutively

\begin{tabular}{|c|c|c|c|c|c|c|c|c|}
\hline \multirow{3}{*}{ Strain } & \multirow{3}{*}{$\begin{array}{l}\text { Inoculum } \\
\text { per } 10 \mathrm{ml}\end{array}$} & \multirow{3}{*}{$\begin{array}{l}\text { Type of } \\
\text { penicillin }\end{array}$} & \multicolumn{6}{|c|}{ Number of survivors after exposure overnight to } \\
\hline & & & \multirow[t]{2}{*}{$\begin{array}{l}\text { penicillin } \\
\text { alone }\end{array}$} & \multirow{2}{*}{$\begin{array}{l}\text { fusidic } \\
\text { acid } \\
\text { alone }\end{array}$} & \multirow{2}{*}{$\begin{array}{c}\text { fusidic acid } \\
\text { + penicillin } \\
\text { added } \\
\text { together }\end{array}$} & \multirow{2}{*}{$\begin{array}{c}\text { penicillin } \\
+ \text { fusidic } \\
\text { acid } \\
\text { after } 2 \mathrm{hr}\end{array}$} & \multicolumn{2}{|c|}{$\begin{array}{l}\text { fusidic acid } \\
+ \text { penicillin } \\
\text { after }\end{array}$} \\
\hline & & & & & & & $2 \mathrm{hr}$ & $6 \mathrm{hr}$ \\
\hline \multirow[t]{2}{*}{ Col } & $4 \times 10^{5}$ & Benzyl- & 2 & 17 & 340 & 2 & 805 & ... \\
\hline & $\begin{array}{r}10^{7} \\
5 \times 10^{5}\end{array}$ & $\begin{array}{l}\text { penicillin } \\
\text { Methicillin } \\
\text { Methicillin }\end{array}$ & $\begin{array}{r}645 \\
4\end{array}$ & $\begin{array}{r}N \\
169\end{array}$ & $\underset{368}{C}$ & $\begin{array}{r}406 \\
\ldots\end{array}$ & $\begin{array}{c}\mathrm{C} \\
\ldots\end{array}$ & $2 \ddot{20}$ \\
\hline Clo & $8 \times 10^{5}$ & Cloxacillin & 27 & 62 & 205 & 36 & 201 & ... \\
\hline \multirow[t]{2}{*}{ Aun } & $6 \times 10^{5}$ & Benzyl- & 105 & 48 & 51 & 5 & 10 & $\ldots$ \\
\hline & $5 \times 10^{5}$ & $\begin{array}{l}\text { penicillin } \\
\text { Methicillin }\end{array}$ & 23 & 9 & 9 & 2 & 4 & $\ldots$ \\
\hline
\end{tabular}

$$
\mathrm{N}=1000-3000 ; C=\text { confluent }(>3000) \text {. }
$$

showed indifference, in that the effect of the mixture was indistinguishable from that of the more actively bactericidal component-in this case fusidic acid.

One strain, Col, shown to exhibit two-way antagonism with benzylpenicillin or methicillin, and another, $\mathrm{Clo}$, shown to behave similarly with cloxacillin, were exposed sequentially to fusidic acid and the relevant penicillins, the second agent being added $2 \mathrm{hr}$ after the first. In each case, the effect of the penicillin prevailed when it was added first, being unaffected by the addition of fusidic acid $2 \mathrm{hr}$ later. On the other hand, the effect of fusidic acid was impaired by the addition of penicillin $2 \mathrm{hr}$ later, in that this combination exhibited the same reduced effect as was obtained when the two agents were added together (table IV). When the addition of penicillin was delayed for $6 \mathrm{hr}$, however, the number of survivors was similar to that obtained after exposure to fusidic acid alone. A penicillinsensitive strain, Aun, which showed indifference (in the sense that in mixtures the effect of the more bactericidal agent, fusidic acid, prevailed) yielded fewer survivors when exposed to mixtures in which the addition of the penicillin and fusidic acid were separated by $2 \mathrm{hr}$ than in any other conditions. 
Turbidimetric studies. Several strains showing typical two-way antagonism were examined in the turbidimetric system, in which they all gave similar results. Fig. 2 shows the normal growth curve (a) of the Col strain of Staph. aureus and the effect of adding $3 \mu \mathrm{g}$ per ml fusidic acid (b) and $15 \mu \mathrm{g}$ per ml methicillin (c). Fusidic acid caused an almost immediate reduction in the slope of the growth curve, followed after a variable length of time (2-4 hr) by a "lytic" (reducedopacity) phase. Opacity due to resistant variants appeared after prolonged incubation, the actual time taken varying from experiment to experiment. Methicillin also had an immediate growth-slowing effect with a subsequent fall in opacity, but this occurred sooner and proceeded more gradually.

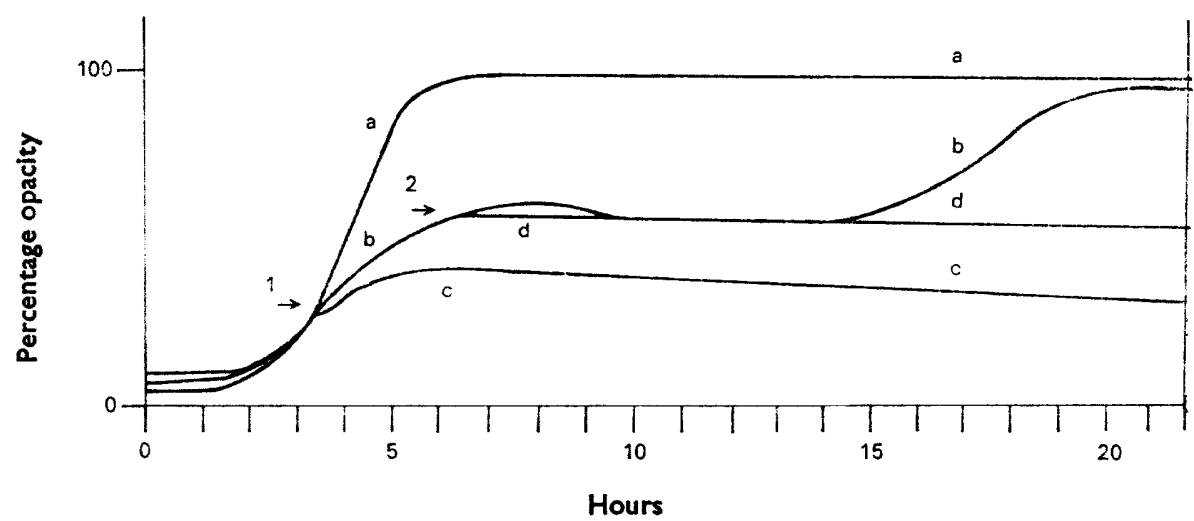

FIG. 2. Continuous opacity record of the Col strain Staphylococcus aureus. Normal growth curve (a); fusidic acid, $2 \mu \mathrm{g}$ per ml, added at first arrow (b); methicillin, $15 \mu \mathrm{g}$ per ml, added at 1st arrow (c); and fusidic acid, $2 \mu \mathrm{g}$ per ml, added at first arrow, and methicillin, $15 \mu \mathrm{g}$ per $\mathrm{ml}$ added at 2 nd arrow (d).

When fusidic acid and methicillin were added together to a growing culture of strain $\mathrm{Col}$, which showed two-way antagonism in the filtration studies, the subsequent trace was similar to that obtained with methicillin alone. When methicillin was added to it, followed $2 \mathrm{hr}$ later by fusidic acid, the trace was still indistinguishable from that produced by methicillin alone. On the other hand, when fusidic acid was added first, followed by methicillin (curve $d$ in fig. 2) the rate of growth was immediately slowed further and the emergence of resistant mutants abolished.

Morphological studies. Because the morphological changes in staphylococci after exposure to penicillin are profoundly different from those after exposure to fusidic acid (Greenwood and O'Grady, 1969 and 1972), it is possible to trace the interaction of these substances by observing the morphological effects of various combinations. These changes are best observed in the scanning electron microscope, but some idea of them can be gained by light microscopy.

Normal cells of the Clo strain as seen in the scanning electron microscope are shown in fig. 3 and the effects of exposure to fusidic acid for 1 and $3 \mathrm{hr}$ in figs. 4 and 5. When cloxacillin and fusidic acid were added together, the fusidic-acid effect was almost totally suppressed (fig. 6) and the predominant response after 3 hours' exposure was that attributable to the penicillin (fig. 7). When cloxacillin 
was added first, the fusidic acid produced no observable morphological effect, even after prolonged exposure. When the fusidic acid was added before cloxacillin, a proportion of the cells collapsed as expected under the influence of the first agent, but there was still some evidence of characteristic penicillin-mediated damage even in cells that had obviously succumbed to fusidic acid (fig. 8). Similar effects were demonstrated by light microscopy on staphylococci exposed to combinations of fusidic acid with benzylpenicillin or methicillin.

\section{Discussion}

Both synergy and antagonism have been reported for combinations of fusidic acid and penicillins (Barber and Waterworth, 1962; Jensen and Kiaer, 1964; Mouton and Koelman, 1966; Jensen and Lassen, 1969). Synergy has been attributed to penicillinase-producing cells being suppressed by fusidic acid, and variants genotypically resistant to fusidic acid being killed by the penicillin. This type of synergy is said to occur only with strains of staphylococci producing a relatively small amount of penicillinase and is not seen with penicillinasestable penicillins (Waterworth, 1963).

Antagonism between fusidic acid and penicillins has been explained as the result of the "bacteristatic" fusidic acid interfering with active cell growth, which penicillin requires to be effective. The finding (which we confirm) that antagonism disappears if the penicillin is added 2 hours before the fusidic acid, has been held to support this view (Jensen and Lassen, 1969).

Like others (Mouton and Koelman) we found that antagonism between fusidic acid and penicillins is not a universal phenomenon affecting all strains of $S$. aureus. With one of our strains (Tho) the combined effect of penicillinase production and the ready emergence of fusidic acid-resistant variants from a rather high inoculum gave the pattern of interaction described by Waterworth. Evidence for the important effect of penicillins in preventing the emergence of fusidic acid-resistant mutants is also provided by the fact that, although we habitually tested persisting populations for fusidic acid-resistant variants, they were never found after exposure to fusidic acid in the presence of penicillins.

Apart from this type of interaction we were able to distinguish three distinct patterns. In the first, shown by the strains Wat and Bat, fewest survivors were recovered after exposure to penicillins alone, more after exposure to mixtures of penicillins with fusidic acid and most after exposure to fusidic acid alone. With these strains there was one-way antagonism of the penicillins by fusidic acid and this effect was more marked when the combination included methicillin than when it included benzylpenicillin, suggesting that methicillin is more sensitive than benzylpenicillin to the antagonistic effect of fusidic acid. In the second pattern, there was indifference between the agents in that the effect of the agent that exerted the greater bactericidal effect on the strain (fusidic acid for strains Aun and Cro and penicillins for Sho) prevailed.

In the final pattern, shown by the great majority of the strains examined, there was two-way antagonism in which more survivors were recovered after exposure to mixtures of penicillins and fusidic acid than after exposure to any 
agent alone. When the agents were added separately it was found that, with the majority of strains, when a penicillin was allowed to act first the result was unaffected by the subsequent addition of fusidic acid, but that, when a penicillin was added two hours after the addition of fusidic acid, the pattern of response was altered.

We conclude from all these findings that with many strains of $S$. aureus not only is the effect of penicillin antagonised by fusidic acid, as previously described, but penicillins interfere with the lethal effect of fusidic acid. When the penicillin is added first the killing observed is attributable solely to the penicillin; and indeed the number of survivors recovered after exposure to both agents when the penicillin was given a 2 -hour start was usually found to be very close to the figure obtained for the penicillin alone (table IV). The inhibition of the penicillin effect when the two agents were added together, or when the fusidic acid was added first, would seem to lie in the inhibition of protein synthesis, which is the primary effect of fusidic acid (Harvey et al., 1967; Tanaka et al., 1968), but cannot be expressed in terms of a "bacteristatic" agent interfering with a "bactericidal" one, because fusidic acid is actively bactericidal for staphylococci and was in fact more bactericidal for a number of the strains tested than were the penicillins. It is presumably cells that survive the destructive effect of fusidic acid and yet are prevented from synthesising polypeptides and hence growing that are inaccessible to penicillin action. What is particularly interesting is that fusidic acid should be antagonised by penicillins, which inhibit the transpeptidation step in bacterial cell wall synthesis (Tipper and Strominger, 1965; Wise and Park, 1965), an event spatially far removed from the ribosomal site of fusidicacid action. The possibility that the two substances react together chemically in some way is unlikely, because increasing the fusidic acid concentration 25 -fold did nothing to overcome penicillin antagonism with one of our strains.

The inhibition of protein synthesis brought about by fusidic acid may weaken the cell wall in some way, because the cells collapse. It may be that the bactericidal action of fusidic acid is mediated by the normal autolytic processes involved in cell wall growth, which continue to function after the protein-synthesising machinery is halted. Scanning electron microscopy showed that these secondary destructive changes were prevented by the presence of cloxacillin, and hence it is presumably at the level of the cell wall that penicillin-mediated antagonism operates.

With at least some strains of $S$. aureus, this type of antagonism is common to several inhibitors of protein synthesis. We have previously shown by scanning electron microscopy that cell-wall collapse, similar to that which follows exposure of staphylococci to fusidic acid, is demonstrable with other inhibitors of protein synthesis, such as erythromycin and lincomycin (Greenwood and O'Grady, 1972); and light microscopy shows similar effects on exposure to chloramphenicol and tetracycline.

Whatever the mechanism of two-way antagonism, it is evidently exhibited by the majority of strains of staphylococci and its relevance to the treatment of severe staphylococcal infection with fusidicacid plus penicillins requires comment. Our view is that the antagonism so easily demonstrated in the laboratory is 
unlikely to be of clinical significance for two reasons. The first is that, in most examples of antagonism with organisms readily killed by either agent alone, the bactericidal effect of the combination still reduces the original bacterial population by 1000 -fold or more. In a conventional test of bactericidal activity, with an inoculum of $10^{5}$ or $10^{6}$ organisms per $\mathrm{ml}$ and subcultivation of a loopful from tubes showing no growth after overnight incubation (Garrod and O'Grady, 1971), a 1000-fold reduction in the original inoculum results in sterile subcultures and the conclusion that the mixture is effectively bactericidal. Moreover, in formal tests of combined bactericidal activity used to select optimum therapy for bacterial endocarditis, mixtures producing a 1000 -fold reduction of the bacterial inoculum are regarded as therapeutically acceptable (Jawetz et al., 1955).

The second reason for doubting the clinical significance of two-way antagonism is that the effect of the mixture progressively approximates to that of fusidic acid alone as the addition of the penicillin is delayed (table IV). In practice, the very marked differences in the pharmacological half-lives of the agents (fusidic acid $12 \mathrm{hr}$, benzylpenicillin $30 \mathrm{~min}$., methicillin $1 \mathrm{hr}$, cloxacillin $1.5 \mathrm{hr}$ ) ensures that, with the exception of the first dose in ordinary dosage schedules, penicillin additions will be made at times when the concentration of penicillin has fallen to low levels but that of fusidic acid is still sustained. In these circumstances, penicillin still exerts the important effect of controlling the emergence of fusidic acid-resistant mutants. In endocarditis, the site of bacterial proliferation may be exposed to both agents in a way that resembles the conditions in which antagonism is seen but the in vitro tests necessary before embarking on therapy will establish whether or not the response of the particular infecting strain to combined therapy is likely to be advantageous. Setting aside this special case, it does not appear that clinically significant interaction is likely to occur, and such evidence as there is from the treatment of patients (Jensen and Lassen, 1969) is in keeping with this conclusion.

\section{SUMMARY}

Interactions were studied between fusidic acid and each of several penicillins in their effect on both penicillinase-positive and penicillinase-negative strains of Staphylococcus aureus. Estimation of the number of staphylococci that survived overnight exposure to the antibiotics, alone and in combination, showed three types of interaction.

In the commonest type, exhibited by more than half the penicillinase-positive and almost all the penicillinase-negative strains, there was two-way antagonism; more staphylococci survived overnight incubation in the presence of fusidic acid plus a penicillin than in the presence of either agent alone. Further evidence that penicillin antagonised the action of fusidic acid against these strains was provided by scanning electron microscopy, which revealed that the cell-wall collapse that followed the action of fusidic acid was inhibited by the presence of a penicillin.

In the second type of interaction there was one-way antagonism of penicillin by fusidic acid; least survivors were recovered after incubation with a penicillin alone, more from the mixture and most from fusidic acid alone. 
The remaining strains showed "indifference", in that the effect of the more bactericidal agent-which against some strains was fusidic acid-prevailed. Even when the effect of penicillin on the bulk of the bacterial population was antagonised, the presence of penicillin always prevented the emergence of fusidic acid-resistant mutants.

We are indebted to Leo Laboratories, Ltd for a grant towards the cost of this work.

\section{REFERENCES}

Barber, Mary, and Waterworth, Pamela M. 1962. Antibacterial activity in vitro of fucidin. Lancet, Lond., 1, 931.

BIGGER, J. W. 1944. Treatment of staphylococcal infections with intermittent sterilization. Lancet, Lond., 2, 497.

Garrod, L. P., AND O'Grady, F. 1971. Antibiotic and chemotherapy, 3rd ed., Edinburgh and London, p. 470.

GreENWOOD, D., AND O'Grady, F. 1969. Antibiotic induced surface changes in microorganisms demonstrated by scanning electron microscopy. Science, N.Y., 163, 1076.

GreENwOOD, D., AND O'GradY, F. 1972. Scanning electron microscopy of Staphylococcus aureus exposed to some common anti-staphylococcal agents. J. Gen. Microbiol., 70, 263.

Gunnison, J. B., Fraher, M. A., AND JAWETZ, E. 1964. Persistence of Staphylococcus aureus in penicillin in vitro. J. Gen. Microbiol., 35, 335.

HALE, C. M. F. 1953. The use of phosphomolybdic acid in the mordanting of bacterial cell walls. Lab. Practice, 2, 115.

HARVEY, C. L., Sin, C. J., AND Knight, S. G. 1967. In Antibiotics, vol. 1, Mechanism of action, edited by D. Gottlieb and P. D. Shaw, New York, p. 404.

Jawetz, E., Gunnison, J. B., Coleman, V. R., AND Kempe, H. C. 1955. A laboratorytest of bacterial sensitivity to combinations of antibiotics. Am. J. Clin. Path., 25, 1016.

Jensen, K. A., AND KIAER, I. 1964. Fucidin-a study on problems of resistance. Acta. path. microbiol. scand., 60, 271.

Jensen, K., AND LAssen, H. C. A. 1969. Combined treatment with antibacterial chemotherapeutic agents in staphylococcal infections. $Q$. $J l$ Med., 38, 91.

Mouton, R. P., AND Koelman, A. 1966. The interaction patterns of combined antibacterial agents. Chemotherapia, 11, 10.

Tanaka, N., Kinoshita, T., AND Masurawa, H. 1968. Mechanisms of protein synthesis inhibition by fusidic acid and related antibiotics. Biochem. Biophys. Res. Commun., 30, 278.

TIPPER, D. J., AND STRominger, J. L. 1965. Mechanism of action of penicillins: a proposal based on their structural similarity to acyl-d-alanyl-d-alanine. Proc. Natn. Acad. Sci. U.S.A., 54, 1133.

Waterworth, Pamela M. 1963. Apparent synergy between penicillin and erythromycin or fusidic acid. Clin. Med., 70, 941.

Watson, B. W., GAuci, C. L., Blache, L., AND O'Grady, F. W. 1969. A simple turbidity cell for continuously monitoring the growth of bacteria. Physics Med. Biol., 14, 555.

WISE, E. M., AND PARK, J. T. 1965. Penicillin: its basic site of action as an inhibitor of a peptide cross-linking reaction in cell wall mucopeptide synthesis. Proc. Natn. Acad. Sci. U.S.A., 54, 75. 